\title{
Investigation of Customer and Technical Requirements for Designing an Ergonomics Notebook Soft Case using Quality Function Deployment (QFD) Approach
}

\author{
Hilma Raimona Zadry ${ }^{* 1}$ and Defri Arif Irfansyah ${ }^{2}$ \\ Department of Industrial Engineering, Faculty of Engineering, \\ Universitas Andalas \\ Kampus Unand Limau Manis, Padang, West Sumatera, Indonesia \\ ${ }^{* 1}$ hilma@ft. unand.ac.id; ${ }^{* 2}$ defryirfanseyahoo.co.id
}

\begin{abstract}
Notebook experienced rapid growth following the human needs. This is evidenced by the increase of notebook sales every year. The problem of shortage and mismatch facilities and supporting infrastructure causes of notebook users force their capacity to use the notebook with non ergonomic position. A preliminary survey through interviews found that the notebook soft case not yet provide ease of mobilization, convenience of use, and protection of health to the users. Therefore it is required an alternatives design of notebook soft case which is ergonomics and multifunction. One of the methods used to design the notebook soft case is Quality Function Deployment (QFD). In this study, QFD is implemented to determine the customer and technical requirements. The results indicate that the material selection which has impact resistant and waterproof is very important to design an ergonomics and multifunctional notebook soft case.
\end{abstract}

\section{Introduction}

Since the mid-1970s, the development of technology, especially computer technology is increasing very rapidly along with the times. Advances in computer technology produce a very rapid development of the computer and its use is widespread [1]. Computers then evolved toward smaller size, from desktop into a notebook [2]. The use of notebook today is very rapidly compared to desktop. People prefer notebooks because its more flexible and fashionable [3].

The increasing quantity of laptop users is not comparable with the availability of facilities and infrastructure support in the public space. One of them is to use notebook on the lap in a long time. It can cause pain in the muscles, back, waist, neck, thighs, eye disorders and impaired concentration [4]. It also can cause skin damage because of the radiation [5]. Another thing to be a priority in the notebook uses is mobilization and protection. Notebooks require protection from external

[Type text] 
threats that can cause physical defects or damage to the notebook system. Based on the above reasons, it gives birth to a notebook soft case. Nowadays, notebook soft case becomes a trend among notebook users. Soft case also takes on the role as a notebook bag that is simple, practical, lightweight, and easy to use fashionable [3].

Preliminary survey through interviews found that the notebook soft case still not provide ease of mobilization, protection, comfort and health assuredness for users when using a notebook. In addition, the existing notebook soft case cannot cover the lack of facilities and infrastructure availability to support the use of a notebook in a public space. Based on the above information, it can be concluded that the notebook soft case on the market today are still not satisfy the users. Therefore this study investigates the customer and technical requirements related to the notebook soft case which is the preliminary stages for designing ergonomics and multifunctional notebook soft case.

With regard to the design methods for new product development, Quality Function Deployment (QFD) is an important methodological approach to increase customer satisfaction and reduce the product costs and development cycle time. It is also an ultimate tool to increased time and resources saving throughout all stages - design to production planning [6]. QFD has been successfully applied by industries around the world [7-9]. Therefore, this study used QFD method to investigate the customer and technical requirements for designing ergonomics and multifunctional notebook soft case.

\section{Methodology}

\subsection{Participants}

There were 115 university students from various universities in Padang City; West Sumatera participated in the study. Forty participants were involved in the survey through interview, while 75 participants were involved in answering the survey questionnaires. The criteria of the participants are those who usually use notebook and the soft case in everyday activities. The participants were randomly selected by personal visit and they were full consent to participate. Data was collected from November to December 2014.

\subsection{Data Collection}

Determining the user needs is probably the most important step in the product planning process. Information about the customer needs and their priorities can be gained through various marketing methods, e.g. questionnaires, interviews, and brainstorming techniques [10]. This study collects data using survey methods, 
through interview and questionnaire. The interviews were conducted to know in general how customers respond to the presence of notebook soft case on the market today as well as the characteristics of the customers towards the desired notebook soft case in the future. The interview is a preliminary stage that serves as a reference in designing the research questionnaire. It is also a method to get an initial picture of consumer expectations for designing an ergonomics notebook soft case.

The survey questionnaire was developed based on the data from the initial interviews. It also refers to the dimensions of quality according to David A. Garvin [11]. The criteria used are performance, features, durability, conformance to standards, aesthetics as well as the price. The questionnaire aims to investigate the customer needs and desires related to the notebook soft case. It covers a range of topics including personal backgrounds and customer requirements to the design of notebook soft case. Scale used for the design of the questionnaire is a Likert rating scale with a range of 1-5 for the assessment is not important (1) to very important (5).

\subsection{Data Analysis}

The collected survey questionnaires were tested for validation and reliability. Then, the collected data were processed using QFD design through House of Quality (HoQ). HoQ consists of several activities supported by various tables and matrices. The basic idea is to translate customers' requirements into the appropriate technical requirements for each stage of product development and production. The procedures of QFD design in this study are divided into the following steps:

a. Determine the customer requirements and the customer important ratings

b. Determine the technical characteristics

c. Translating customer requirements into measurable technical requirements

d. Determine the relationship of each technical characteristics

e. Determine the priority of the technical characteristics

\section{Results}

\subsection{Interview and Questionnaire}

The process of identification of customer needs is the first step in designing a product. The customer requirements were obtained from the initial interview survey is presented in Table 1. 
Table 1. List of Customer Requirements for Notebook Soft case derived from Interviews

\begin{tabular}{llc}
\hline No & Customer Requirements & Total \\
\hline 1 & Safe and protected & 26 \\
2 & Attractive design & 7 \\
3 & Thin design & 2 \\
4 & Waterproof & 22 \\
5 & Lightweight & 5 \\
6 & Availability of storage for goods & 5 \\
7 & Availability of portable desk & 3 \\
8 & Availability of external fan & 1 \\
9 & Multifunction & 4 \\
10 & Adjustable and multifunction straps & 10 \\
11 & Thick foam on the straps & 4 \\
12 & Affordable prices & 1 \\
13 & Comfortable when used and carried & 7 \\
\hline
\end{tabular}

Based on those needs obtained from interview, a questionnaire was developed to gain reliable data about customer requirements with respect to customer satisfaction. It also refers to the five dimensions of Garvin quality namely performance, features, durability, conformance, aesthetics, and price. The lists of criteria related to the customer requirements in the questionnaire were presented in Table 2.

Table 2. The lists of criteria related to the customer requirements in the questionnaire

\begin{tabular}{ll}
\hline Quality Dimension & Criteria \\
\hline Performance & Comfortable when used \\
& Comfortable when carried \\
& Safe when used \\
\hline Features & Availability of back strap \\
& Availability of tote strap \\
& Adjustable straps \\
& Thick foam on the straps \\
& Availability of storage for goods \\
& Availability of raincoat \\
& Availability of external fan \\
& Availability of tilt adjusting \\
& Availability of portable desk \\
& Availability of wheels \\
& The closed soft case is semi-automatic \\
\hline Durability & Strong material \\
\hline
\end{tabular}




\begin{tabular}{ll}
\hline & Material safe for health \\
& Material protects from impact \\
& Lightweight material \\
& Waterproof material \\
\hline Conformance & In accordance with the notebook size \\
\hline Aesthetics & Simple and minimalist \\
& Thin \\
& Colorful \\
\hline Price & In accordance with the purchasing power \\
& In accordance with the quality offered \\
& In accordance with the perceived benefits \\
\hline
\end{tabular}

\subsection{Quality Function Deployment (QFD)}

The identification of the customer requirements was conducted by distributing questionnaires to 75 participants. The answers were weighted in order to obtain the measured value. Measurement scale used was a Likert scale with the scale from 1 (not important) to 5 (very important). The collected questionnaire data were tested for validity, reliability and adequacy. The results show that all data obtained were valid, reliable and sufficient for the next analysis. Table 3 shows the customer requirements and customer important ratings for designing multifunctional notebook soft case.

Tabel 3. Customer Important Ratings

\begin{tabular}{llc}
\hline No. & Customer Requirements & $\begin{array}{c}\text { Customer Important } \\
\text { Ratings }\end{array}$ \\
\hline 1 & Material protects from impact & 4.73 \\
2 & Waterproof material & 4.64 \\
3 & In accordance with the purchasing power & 4.61 \\
4 & Safe when used & 4.56 \\
5 & Lightweight material & 4.56 \\
6 & Comfortable when carried & 4.52 \\
7 & Material safe for health & 4.45 \\
8 & In accordance with the quality offered & 4.45 \\
9 & Comfortable when used & 4.43 \\
10 & In accordance with the perceived benefits & 4.40 \\
11 & In accordance with the notebook size & 4.35 \\
12 & Strong material & 4.28 \\
13 & Availability of storage for goods & 4.24 \\
14 & Adjustable straps & 4.17 \\
15 & Availability of raincoat & 4.11 \\
\hline
\end{tabular}




\begin{tabular}{lll}
\hline 16 & Thick foam on the straps & 4.03 \\
17 & Simple and minimalist & 3.99 \\
18 & Availability of tote strap & 3.92 \\
19 & Colorful & 3.59 \\
20 & Availability of external fan & 3.31 \\
21 & Availability of tilt adjusting & 3.31 \\
22 & Thin & 3.25 \\
23 & Availability of back strap & 3.24 \\
24 & Availability of portable desk & 3.11 \\
25 & The closed soft case is semi-automatic & 2.76 \\
26 & Availability of wheels & 2.04 \\
\hline
\end{tabular}

The results from the questionnaire survey in Table 3 revealed information on the average weighting of ergonomic and multifunction demands of notebook soft case. The table shows that of the 26 items of questions posed to the participants, 16 items are considered very important by participants in a notebook soft case. According to the customers, material that can protect the notebook from impacts is the most important need to be met when designing the notebook soft case, followed by waterproof material, in accordance with the purchasing power, etc. This information was used directly in the QFD analysis as a basis for translating the customer requirements into technical characteristics expressed in technical terms.

Technical characteristics used to represent the voice of developers. Determination of the technical characteristics was done by consultation and discussion with experts in the respective products related to material and manufacturing. The technical characteristics used in the QFD analysis were ergonomics design, dimension, material strength, material type and quality, color variations, external fan design, notebook desk design, and strap design.

The next step is determination of the relationship between the different technical characteristics. It is determined, in order to identify particularly the inverse relationships. An inverse relationship between different product characteristics means that improving one property leads to a deterioration of the other. A strong positive relationship is illustrated with a ' $\sqrt{ }$ ', a positive with a ' $\sqrt{ }$ ', no relationship with 'blank', a strong negative with a ' $x \times$ ' and a negative with a ' $x$ ' [12]. By comparing different technical characteristics, their relationships are identified. For example, the relationship between the material strength with the material type and quality is a strong positive relationship. It means the better the material type and quality, the better the material strength. Relationship between the different technical characteristics is presented in Figure 1. 


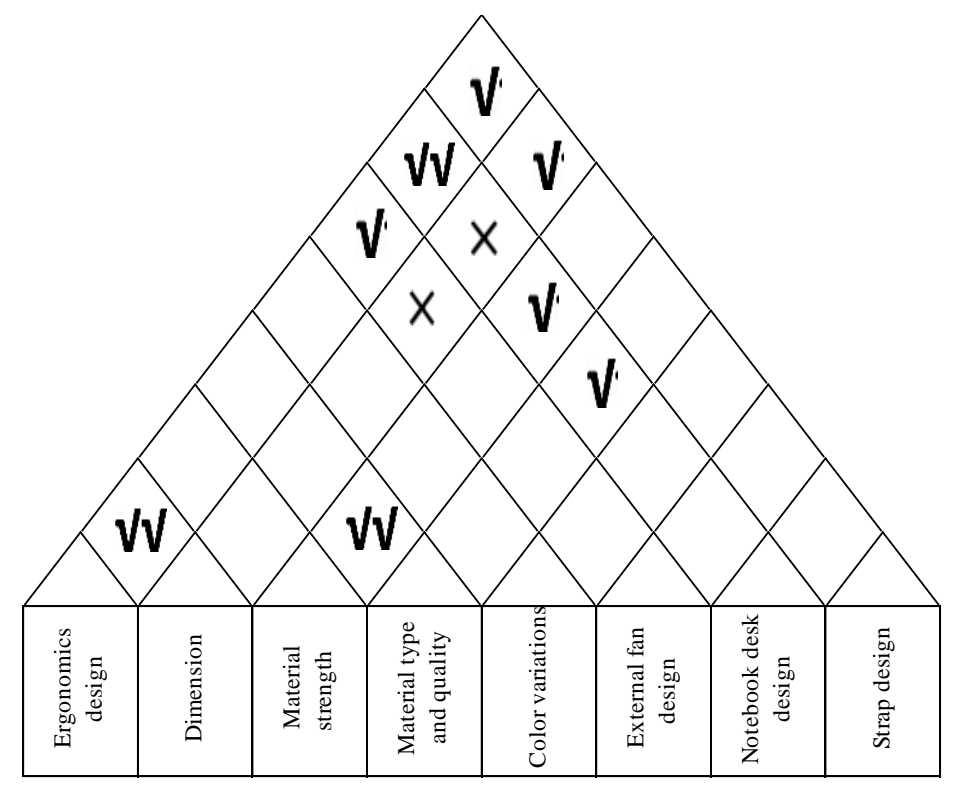

Fig. 1. Relationships between Different Technical Characteristics

The relationships between consumer requirements and technical characteristics have to be established in order to identify important product properties. This relationship is made in the form of a matrix by using the symbols according to Cohen 1995. Based on discussion with experts from material field and manufacturing, the team assigns a 'strong', 'medium', 'weak' or 'no' relationship value to each specific pairing. For this an appropriate scale (9-3-1) is applied, illustrated using symbols $(\bullet-0-\Delta)$. This stage is one of the key elements of the QFD method because it is the one which permits the transition to be made between what the user wants and what the designer offers [13]. Figure 2 shows the relationship between customer requirements and technical characteristics for the design of notebook soft case.

An example of the relationship between the customer requirement and the technical characteristics is waterproof material with the material type and quality which has a strong relationship. That is, the better the selection of the material type and quality, the better the durability of product to the water. After determining the relationship between customer requirements and technical characteristics, the next step is to determine what technical characteristics are influencing the customer satisfaction. It shows which technical characteristics will be a priority in product development. Priority value is determined by multiplying the customer important ratings and numerical weighing of the relationship, then summing these together, each product characteristic is given an overall weighting. 


\begin{tabular}{|c|c|c|c|c|c|c|c|c|c|}
\hline & 总 & 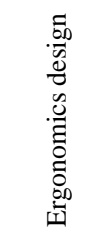 & 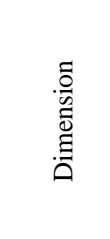 & 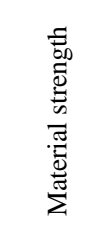 & 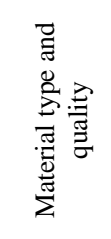 & 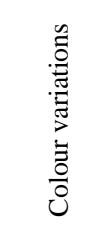 & 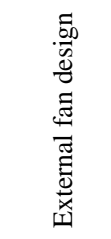 & 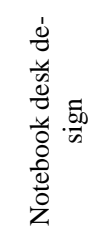 & 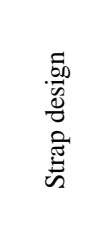 \\
\hline Customer Requirements & $\begin{array}{l}\text { Customer } \\
\text { Important } \\
\text { Ratings }\end{array}$ & & & & & & & & \\
\hline Comfortable when used & 4.43 & $\cdot$ & & & & & $\cdot$ & $\bullet$ & \\
\hline Comfortable when carried & 4.52 & $\bullet$ & $\cdot$ & & & $\mathrm{O}$ & & & $\mathrm{O}$ \\
\hline Safe when used & 4.56 & & & $\bullet$ & $\bullet$ & & o & $\bullet$ & \\
\hline Availability of back strap & 3.24 & & & & & $\Delta$ & & & $\Delta$ \\
\hline Availability of tote strap & 3.92 & & & & & $\Delta$ & & & o \\
\hline Adjustable straps & 4.17 & • & o & & & & & & $\mathrm{O}$ \\
\hline Thick foam on the straps & 4.03 & & & & & & & & $\Delta$ \\
\hline $\begin{array}{l}\text { Availability of storage for } \\
\text { goods }\end{array}$ & 4.24 & o & & & & & & & \\
\hline Availability of raincoat & 4.11 & $\Delta$ & & & & & & & \\
\hline Availability of external fan & 3.31 & $\mathrm{o}$ & o & & & & o & & \\
\hline $\begin{array}{l}\text { Availability of tilt adjust- } \\
\text { ing }\end{array}$ & 3.31 & o & o & & & & & $\Delta$ & \\
\hline $\begin{array}{l}\text { Availability of portable } \\
\text { desk }\end{array}$ & 3.11 & o & o & o & & $\Delta$ & & o & \\
\hline Availability of wheels & 2.04 & $\Delta$ & & & & & & & \\
\hline $\begin{array}{l}\text { The closed soft case is } \\
\text { semi-automatic }\end{array}$ & 2.76 & $\Delta$ & & & & & & & \\
\hline Strong material & 4.28 & & & $\cdot$ & & & & & \\
\hline Material safe for health & 4.45 & & & & $\cdot$ & & & & \\
\hline $\begin{array}{l}\text { Material protects from im- } \\
\text { pact }\end{array}$ & 4.73 & & & • & $\bullet$ & & o & o & \\
\hline Lightweight material & 4.56 & & & & o & & o & $\cdot$ & \\
\hline Waterproof material & 4.64 & & & $\bullet$ & $\cdot$ & & & & \\
\hline $\begin{array}{l}\text { In accordance with the } \\
\text { notebook size }\end{array}$ & 4.35 & & $\bullet$ & & & & o & o & \\
\hline Simple and minimalist & 3.99 & & o & & & $\Delta$ & & & \\
\hline Thin & 3.25 & & o & & & & & o & \\
\hline Colorful & 3.59 & & & & & $\mathrm{O}$ & & & \\
\hline $\begin{array}{l}\text { In accordance with the } \\
\text { purchasing power }\end{array}$ & 4.61 & & & • & o & $\Delta$ & & & \\
\hline $\begin{array}{l}\text { In accordance with the } \\
\text { quality offered }\end{array}$ & 4.45 & & & & $\bullet$ & & & & \\
\hline $\begin{array}{l}\text { In accordance with the per- } \\
\text { ceived benefits }\end{array}$ & 4.40 & & & & o & & o & o & \\
\hline \multicolumn{2}{|c|}{ Priority Values } & 168.90 & 143.20 & 214.80 & 246.30 & 43.20 & 117.60 & 184.70 & 45.10 \\
\hline \multicolumn{2}{|l|}{$\%$ Priority } & $14.51 \%$ & $12.30 \%$ & $18.46 \%$ & $21.16 \%$ & $3.71 \%$ & $10.10 \%$ & $15.87 \%$ & $3.88 \%$ \\
\hline
\end{tabular}

Fig. 2. Relationships between Customer Requirements and Technical Characteristics 


\section{Discussion}

The survey shows that of the 26 items of questions posed to the respondents, 16 items are considered very important by respondents in a notebook soft case. Materials that can protect the notebook from impact become the highest priority of the customer requirements with a value of 4.73 . It is because it relates directly to the notebook security from external threats. Proper material selection is certainly considered to protect the notebook from a crash that could result in damage and defects on the notebook. Notebook falls from height are things that might happen, thus, it is needed a good material to protect notebook from impact. Those kinds of materials commonly used to protect the notebook from impact are foam. Foam is a material that can dampen vibration on impact. The thicker the foam wind used, the better its function in protecting the notebook from impact.

Waterproof material are the second highest of the customer important ratings with a value of 4.64. Notebooks are vulnerable device be damaged if exposed to water. Assuredness notebook security in the mobilization is very important for customers. Selection of waterproof material is the perfect solution to maintain security of notebook from damage in unfavorable conditions such as rain. Waterproof material selection will surely make customers more comfortable and not have to worry to carry a notebook in the current rainy conditions. These materials such as cloth that is impermeable to water. It is a combination of the polyester and nylon.

Price conformity with the purchasing power was in the third place of customer important ratings with a value of 4.61. The design of notebook soft case was adjusted to the purchasing power of the people. Therefore, in the choice of materials and components of the design, it is considered to use affordable and qualified materials according to the specifications of customer requirements. Availability of wheels on the notebook soft case is in the last place of customer important ratings with a value of 2.04. Giving the wheels on the notebook soft case adversely affect the security of notebook such as knocks and falls. Notebook position should be in a fixed position during use.

Quality Function Deployment method aims to design more targeted products in accordance with customer desires. QFD translates customer requirements into the form of product attributes to meet the customer requirements. This study use QFD until HOQ phase 1. The next phase until product design will be done at the future research.

\section{Conclusion}

This research has used the Quality Function Deployment (QFD) method to investigate the customer and technical requirements in designing the ergonomics and multifunctional notebook soft case. The results indicate that the material selection which has impact resistant and waterproof is very important to design an ergonomics and multifunctional notebook soft case. For the future research, TRIZ me- 
thod will be used to solve the contradictions between technical requirements continued with the development of QFD phase 2 to determine the design characteristics. Thus, the ergonomics and multifunctional notebook soft case will be designed in accordance with the conditions and the latest technology.

\section{References}

1. Zulkarnaian, A. Peranan Laptop Support Dalam Mengurangi Kelelahan pada Pengguna Laptop. INSAN. 14(2) (2012) 97-107.

2. Sudirman, I. and Wahono, R. S. Sejarah Komputer. Kuliah Pengantar Ilmu Komputer.com. (2003).

3. Hendra and Octaviani, D. F. Keluhan Kesehatan Akibat Penggunaan Laptop pada Mahasiswa FKM UI. Jurnal Universitas Indonesia. (2012) 1-19.

4. Thandung, D., Lintong, F. and Supit, W. Tingkat Radiasi Elektromagnetik Beberapa Laptop dan Pengaruhnya Terhadap Keluhan Kesehatan. Jurnal eBiomedik. 1(2) (2013) 1-7.

5. Saptriyawati. Dampak Negatif Memangku Laptop. https://saptriyawati.wordpress.com/2011/04/16/dampak-negatif-memangkulaptop/

6. Nikhil Chandra Shil, M. Ameer Ali, and Nafize Rabbani Paiker. Robust Customer Satisfaction Model using QFD', International Journal of Productivity and Quality Management, 6 (1) (2010) 112-36.

7. Bergman, B. K. B. Quality from customer needs to customer satisfaction. (1994) London: McGraw-Hill.

8. Geuma, Y. J., Kwak, R., and Yongtae Park, Y. T. Modularizing services: A modified HoQ approach. Computers \& Industrial Engineering, 62 (2012) 579590.

9. Vezzetti, E., Moos, S., and Kretli, S. A product lifecycle management methodology for supporting knowledge reuse in the consumer packed goods domain. Computer-Aided Design, 43 (2011) 1902-1911.

10. Bergquist, K. and Abeysekera, J. Quality Function Deployment (QFD) - A means for developing usable products. Int J Ind Ergon 18 (1996) 269-275.

11. Garvin, David A. Managing quality: The strategic and competitive edge. Simon and Schuster (1988).

12. Cohen, L. Quality Function Deployment : How to Make QFD Work for You. Massachusetts: Addison-Wesley Publishing Company (1995).

13. Marsot, J. QFD: a methodological tool for integration of ergonomics at the design stage. Appl Ergon 36(2) (2005) 185-192. 